schools, many were critical of the courses they had followed in university education departments in relation to subsequent work in schools. 28 per cent of them thought that the history of education was useless as part of their conventional course, and a further 50 per cent maintained that it was of little value. 94 per cent of the teachers considered that guidance relating to their own subject was of the utmost importance, but recognized the importance of educational psychology and the aims of education as well. More than 80 per cent of teachers thought that methods of teaching conceptually difficult topics, lesson planning and the aims of chemistry teaching deserved a lot of attention.

Answers to a second questionnaire scnt to teachers who had trained in 1965-66 were equally critical. Little attention was given during teaching practice to several topics considered important, and there was rarely any opportunity during teaching practice for many to receive advice from experienced teachers before, after or during lessons. Furthermore, many students were unable to try out class experiments and demonstrations before lessons during teaching practice. The committee suggests that, in view of the short time allotted in many universities to chemistry teaching, coupled with the marked lack of laboratory space and equipment in many of the departments, students often do not have an opportunity to consider these matters. The nature and content of training courses see $m$ to have been so unsatisfactory that between 1955 and 1965 a substantial number of graduates may have decided against undertaking training for this very reason.

The committee considers that university departments of education try to cover too wide a range of subjects, leading to a superficial treatment which is neither useful nor satisfying to graduates. In view of the short time available for training, fewer subjects should be studied and this requires placing subjects in an order of priority. It also emphasizes the need to astablish some means by which experienced teachers can make known to university departments of educat.ion and colleges of education those aspects of study, guidance and training which in their experience would be of greatest value to teachers in the realities of school work. Better provision of laboratories is another recognized need during training.

\section{Tax on Teaching}

The announcement by the Chancellor of the Exchequer in the British budget of increased purchase tax on projectors and tape recorders seems to be producing confusion as well as complaint. At first sight the 50 per cent tax on projectors and 33.3 per cent on tape recorders looks simple enough, but what of teaching machines? No direct mention of them was made in the budget speech; the Inland Revenue declare that no exemption has been stated for them, and that "viewers" are included in the new tax; but ESL, one of the largest manufacturers in Britain of teaching machines, has not yet been told by the Customs and Excise to put up its prices. In the meantime the manufacturers, through their association, BEAMA, have stated their case to the Ministry of Technology and the ministry is in turn making representation to the Treasury.

If prices do rise, local education authorities will be forced to cut down their orders, as allocations are usually for a set sum of money rather than a certain number of machines. Thus a tax on teaching machines will result in money being transferred from one government purse to another, with schools and universities the suffering intermediates. The Association of Education Committees has therefore taken the matter up with the Department of Education and Science and the department is discussing it with the Treasury.

Just what effect this purchase tax would have on education is difficult to estimate. Bodies like the National Centre for Programmed Learning in Birmingham are trying to swell to a flood the trickle of people using audio-visual aids. At present the centre estimates that only five per cent of schools use programmed learning. Equipment is already expensive, and a tax increase now might turn the tide in the other direction. Books are one alternative to electro-magnetic machines for programmed learning, and are likely to be more effective for small budgets. The manufacturers claim that machines are more versatile, take up less space and last longer than books, but there has not yet been time for these claims to be verified. As yet there seems to be no evidence that machine programmes are more effective than books, but they do cover wider ground, in that 70 per cent of the 18,000 programmes available are in machine form.

The National Centre for Programmed Learning is keen to encourage the use of tape recorders and projectors as they are more versatile than conventional "teaching machines", even though work with them is still at an experimental level. It has been shown, for example, that eight-year-olds who cannot read can understand basic scientific concepts which are presented on tape. Machines which are used solely for education purposes could well be exempted from the new purchase tax, but the case of tape recorders and projectors for use in schools is more complicated, as some form of exemption would have to be introduced for educational establishments.

\section{Thames Action}

There was an enthusiastic response to a one-day conference on the River Thames held last Monday, April 1. The conference, sponsored by the Greater London Council in association with the London Boroughs Association, was attended by representatives of the riverside boroughs, the county authorities, voluntary and recreational organizations, professional bodies and commercial undertakings. The conflicting interests of all those concerned with the river were very obvious-at least twenty different authorities have an interest in the 43 miles of the Thames passing through Greater London-but the growing urgency for action may result in constructive co-ordinated planning for the river's future. The very fact that the conference has been held is a step in the right direction. Now there is the machinery for action on a large scale. The Greater London Council has decided, in conjunction with the London Boroughs Association and the other interests, to accept responsibility for the initiation. encouragement and support of action for the improvement of the Thames. A number of schemes are already in the planning stage and some of these were mentioned and discussed at the conference. They included, for example, the redevelopment of the St Katherine 
and Brentford Docks and Thamesmead, the new town now being built between Woolwich and Erith.

An important part of any future planning is the assessment of the river's existing qualities and characteristics-mostly provided for the conference by the Thames-side Environmental Assessment (GLC, 25s.). This assessment was made by a joint team from the Department of Architecture and Civic Design of the GLC and the riverside borough councils. This committee was set up by the GLC and the London Boroughs Association in 1966 and includes officers of the Port of London Authority and various commercial and amenity interests. Other working parties have been established by the GLC and the riverside borough councils, and the GLC has also recently set up a special subcommittee, the Thames Action Subcommittee, which will have the responsibility of encouraging increased use of the river within Greater London for leisure. Things do seem to be moving towards a more co-ordinated policy for the Thames-the test will be if all the interested bodies can pull together.

The fundamental problems of the river's tidal flow, flooding and pollution will have to be solved for the success of the elaborate schemes outlined at the conference, however well-intentioned they may be. The

\section{Sorry, for copyright reasons some images on this page may not be available online}

The river Thames at Greenwich (Fairey Surveys).

river seems to be getting cleaner, which is cheering news, and the leader of the GLC, Mr Desmond Plummer, spoke of $£ 20$ million being spent on the extension to the sewage works at Beckton. The GLC also appears to be taking very seriously the question of a barrier or barrage across the river. This would not only solve the flood problem but it would also improve enormously the amenities of the river (see Nature, 21\%, 800; 1968). The speakers at the conference gave the impression that they were in favour of a fixed barrage across the lower reaches of the river rather than a retractable barrier-Sir Alan Herbert was one who argued on behalf of this cause. The GLC has now taken over responsibility for carrying out a full-scale investigation of tidal flooding and its prevention, and models are being built at the Hydraulics Research Station at Wallingford. The support for a barrage was really the most enlightened aspect of the conference There was of course plenty of enthusiasm in other ways, but any new developments can hardly be attractive to Londoners and tourists alike until the tidal flow is controlled and the Thames returns to its former status as a river instead of its present one as a rubbish dump.

\section{Intellectuals' Holiday Camp}

THE University of Loughborough is already receiving encouraging response to its announcement last week of a new type of vacation course. Three weeks of courses are being arranged in July for technologists, scientists. managers, teachers and-here lies the novelty-for their spouses. Provision is being made for children so that families can be together while parents catch up on some mid-career training. The idea for family courses came from Dr Elfyn Richards, vice-chancellor of the university, and work started on the arrangement of the courses last autumn.

Twenty-four technical courses during the three weeks will cover such subjects as optics, ultrasonics, ergonomics, computers, statistics and management. Two educational courses are being organized, with co-operation from the Association for Science Education and the Schools Council Project in Technology. The first, on applications of knowledge, is designed for teachers of mathematics and physical sciences, and the second, on teaching materials science in schools, is being run with the blessing of the Northern Universities Joint Matriculation Board co-ordinating committee. Both will relate technology in industry to school work.

Cultural courses for spouses, which make up the third series, will cover industrial archaeology, music, drama and new techniques of food production. The idea is that they should be stimulating rather than requiring previous knowledge.

Accommodation is provided on the campus for families at reasonable rates. For example, a man will be charged $£ 10$ for accommodation and a course fee varying with subject from $£ 9$ upwards. His wife will be charged $£ 13$ inclusive of cultural courses and children will cost from $£ 4$ upwards. Fi'ms, bars and sports facilities will be available to parents, with babysitters, play groups and other forms of recreation on hand for the children. While hoping to provide all the facilities of a holiday camp, the university believes that its vacation courses will be more valuable than the description "intellectual Butlins" implies. The state of modern industry is such that scientists and technologists are continually being called on to travel and attend courses away from home. So it is not therefore surprising that these people are reluctant to give up their holidays for further study away from their families.

The courses at Loughborough this year are something: of a pilot scheme, and if successful the idea will be extended to cover the major part of the summer vacation.

\section{Hydrofoils at Leeds}

A LARGE water tank which may solve some of the problems connected with high speed hydrofoils has been built at Leeds University. The tank is in the form of a channel through which up to 50 tons of water per minute can be circulated. In some respects it 